\title{
Isolasi Klebsiella Sp. pada Sapi Bali Berdasarkan Tingkat Kedewasaan dan Lokasi Pemeliharaan serta Pola Kepekaan Terhadap Antibakteri
}

\author{
(ISOLATION KLEBSIELLA Sp. AT BALI CATTLE BASED ON LEVEL OF MATURITY \\ AND BREEDING LOCATION AND THE PATTERN OF SENSITIVITY AGAINST \\ ANTIBACTERIAL)
}

\section{Nyoman Anandiya Ramaditya ${ }^{1}$, Ketut Tono PG ${ }^{2}$, I Gusti Ketut Suarjana ${ }^{2}$, I Nengah Kerta Besung ${ }^{2}$}

${ }^{1}$ Mahasiswa Program Magister Sains Veteriner Universitas Udayana

${ }^{2}$ Laboratorium Mikrobiologi Veteriner Universitas Udayana

J1. PB. Sudirman Denpasar-Bali

Email: anandiya.ramaditya@gmail.com

\begin{abstract}
ABSTRAK
Telah dilakukan penelitian jumlah isolat bakteri Klebsiella sp. pada sapi bali ditinjau dari tingkat kedewasaan dan lokasi pemeliharaannya, serta pola kepekaannya terhadap antibiotika ampisilin, sulfametoksasol dan oksitetrasiklin. Sebanyak 120 usapan hidung sapi bali yang terdiri dari sapi pedet, dara, dan dewasa yang dipelihara pada dataran tinggi dan rendah digunakan sebagai sampel dalam penelitian. Sampel usapan hidung yang didapat dilakukan isolasi dan identifikasi, kemudian dilanjutkan dengan uji kepekaan. Ditemukan bakteri Klebsiella Sp. pada sapi pedet berjumlah sembilan isolat (45\%), sapi dara enam isolat (30\%), dan sapi dewasa lima isolat (25\%). Pada dataran rendah ditemukan $13(65 \%)$ isolat dan dataran tinggi berjumlah tujuh isolat (35\%). Pada uji kepekaan didapatkan hasil antibiotika ampisilin semua isolat sensitif (100\%). Sulfametoksasol resisten empat isolat (20\%), intermediate dua isolat (10\%), dan sensitif 14 isolat (70\%). Oksitetrasiklin isolat yang resisten berjumlah tujuh isolat (35\%), intermediate dua isolat (10\%), dan sensitif 11 isolat (55\%). Hasil penelitian menunjukkan bahwa perbedaan tingkat kedewasaan dan lokasi pemeliharaan sapi bali dapat mempengaruhi perbedaan sebaran bakteri Klebsiella sp. .
\end{abstract}

Kata kunci: sapi bali; dataran tinggi; Klebsiella sp.;dataran rendah; pola kepekaan

\begin{abstract}
Research has been conducted to know the number bacterial isolates of Klebsiella sp. from bali cattle in terms of the level of maturity and the breeding location, also its sensitivity to the antibiotic there are ampicillin, sulfamethoxazole, and oxytetracycline. 120 bali cattle's nasal swabs consisting of calves, heifers, and adult cattle which are breeding on highland and lowland has been used as the isolates in this research. The obtained nasal swab was isolated and identified, then proceed with the sensitivity test. Bacterial of Klebsiella sp. has been found in calves were nine isolates (45\%), heifers were six isolates $(30 \%)$, and adult cattle were five isolates (25\%). While based on the breeding location in the lowland found 13 isolates (65\%) and highland found seven isolates (35\%). In the sensitivity test results were obtained for the antibiotic ampicillin all isolates were sensitive (100\%). sulfamethoxazole resistant four isolates (20\%), intermediate two isolates (10\%), and sensitive 14 isolates (70\%). Oxytetracycline resistant seven isolates (35\%), intermediate two isolates (10\%), and sensitive 11 isolates (55\%). The results showed that differences in the level of maturity and breeding location of bali cattle can affect the distribution of bacteria Klebsiella sp..
\end{abstract}

Keywords: bali cattle; highland; Klebsiella sp.; lowland; sensitivity pattern

\section{PENDAHULUAN}

Sapi bali berasal dari banteng (Bibos banteng) yang telah didomestikasi berabadabad lalu (Chamdi, 2004). Sapi bali merupakan salah satu pemasok kebutuhan daging nasional. Sapi ini merupakan ternak primadona di Bali karena memiliki banyak keunggulan dibandingkan sapi lainnya yaitu memiliki daya adaptasi terhadap lingkungan yang sangat tinggi, misalnya dapat bertahan hidup dalam cuaca yang 
kurang baik, dapat memanfaatkan pakan dengan kualitas yang rendah dan tahan terhadap parasit eksternal maupun internal (Nugraha et al., 2016).

Import sapi dari tahun ke tahun tampaknya tetap tinggi. Hal ini terbukti pada tahun 205, impor daging sapi untuk kebutuhan industri sebanyak 23.880 ton (Jiuhardi, 2016). Dari data tersebut dapat disimpulkan bahwa ternak sapi di Indonesia belum mampu memenuhi kebutuhan daging sapi. Adanya kekurangan produksi disebabkan karena kebutuhan yang terlalu tinggi, dan produksi hasil terbatas, serta adanya beberapa penyakit yang menimbulkan penurunan produksi daging, bahkan ada yang menimbulkan kematian yang disebabkan oleh berbagai penyakit infeksius.

Gunawan et al. (2016) menyatakan bahwa penyakit infeksi pada sapi bali dapat menyerang saluran pencernaan, saluran reproduksi, urinaria, dan sistem respirasi. Penyakit sistem repirasi dapat disebabkan oleh berbagai agen penyakit antara lain bakteri, virus, atau gabungan keduanya, jamur, parasit, agen kimia (mineral), dan agen fisik. Beberapa bakteri yang menyebabkan penyakit pada sistem respirasi ysitu Mycoplasma sp., Pasteurella sp., Corynebacterium pyogenes, Staphylococcus sp., Streptococcus sp., Pseudomonas aeruginosa, Escherichia coli dan Klebsiella sp. (Das dan Qin, 2012).

Klebsiella sp. merupakan bakteri yang ditemukan dalam jumlah kecil pada saluran napas atas. Klebsiella $s p$. merupakan bakteri patogen pootensial dan patogen oportunistik yang sangat penting. Bakteri ini menyebabkan infeksi pada saluran pernapasan atas yaitu pada mukosa hidung dan faring, serta meyebabkan pneumonia dan infeksi saluran kencing akibat infeksi yang meluas (Sikarwar, 2011). Klebsiella sp. mampu menyebabkan penyakit akibat adanya perubahan cuaca, defisiensi nutrisi, kelelahan, kelaparan, dan adanya infeksi parasit (Bren et al., 2013). Kerugian akibat bakteri pada sapi antara lain, penurunan berat badan sapi, bisa menular ke sapi-sapi lain, biaya pengobatan, harga jual sapi menjadi sangat rendah dan pada sapi perah dapat menurunkan produksi susu (Wanapat et al., 2011). Infeksi pada saluran pernapasan bagian atas banyak ditemukan, namun belum pernah ada laporan penelitian yang melakukan isolasi bakteri tersebut.

Produksi ternak seperti sapi bali juga dipengaruhi oleh beberapa faktor salah satunya yaitu faktor lingkungan yang meliputi radiasi, suhu udara, kelembapan, kecepatan angin, curah hujan, dan ketinggian tempat. Suhu memiliki pengaruh yang sangat penting terhadap fase pertumbuhan bakteri. Pada suhu rendah seperti pada dataran tinggi pertumbuhan dan aktivitas bakteri cenderung mengalami perlambatan, sedangkan pada suhu yang tinggi seperti pada dataran rendah bakteri cenderung tumbuh lebih cepat (Kadarsih, 2004). Kerentanan terhadap penyakit juga dipengaruhi oleh umur sapi. Umur sapi ini berkaitan erat dengan imunitas tubuh. Menurut Riko et al. (2012) bahwa sistem imun pada hewan terbagi menjadi dua yaitu imunitas bawaan dan imunitas adiptif. Hewan yang berumur lebih muda hanya memiliki imunitas bawaan saja, sedangkan hewan yang berumur lebih tua sudah memiliki imunitas adiptif.

Adanya infeksi bakteri pada tubuh dapat ditanggulangi dengan pemberian antibakteri. Menurut Boogard (2001) berdasarkan pengamatan lapangan, antibiotika yang lazim digunakan untuk pencegahan dan pengobatan penyakit pada hewan adalah antibiotika golongan penisilin, tetrasiklin, dan sulfonamide. .Keberhasilan pengobatan ditentukan oleh ketepatan dosis, lama pemberian antibakteri, dan pemilihan obat yang tepat.

\section{METODE PENELITIAN}

\section{Materi Penelitian}

Hewan yang dipakai dalam penelitian ini adalah sapi bali yang diklasifikasikan berdasarkan kelompok umur yaitu pedet, dara, dan dewasa. Sampel yang digunakan merupakan usapan hidung dari sapi bali 
yang diperoleh dari beberapa kelompokkelompok ternak yang berada di daerah dataran rendah (Denpasar dan Badung) dan dataran tinggi (Gianyar dan Bangli) di Provinsi Bali.

\section{Metode Penelitian}

Sampel penelitian yang digunakan adalah usapan hidung sapi bali jantan dan betina yang dibedakan berdasarkan tingkat kedewasaan yaitu pedet, dara, dan dewasa dan berdasarkan lokasi pengambilan yaitu pada dataran tiggi dan dataran rendah provinsi Bali. Selanjutnya hasil usapan dimasukan kedalam mikrotube yang berisi media transport (stuart agar). Bakteri yang berasal dari swab nasal ditanam pada eosin methylene blue agar (EMBA) dengan metode garis. Diinkubasikan selama semalaman (24 jam) pada suhu $37^{\circ} \mathrm{C}$, bakteri Klebsiella sp. menunjukan ciri-ciri berwarna pink, koloninya besar dengan diameter 2-5 mm, mukoid, dan cenderung bersatu.

Selanjutnya keesokan harinya dilakukan identifikasi dengan pewarnaan Gram dan uji oksidase serta katalase terhadap koloni bakteri yang menciri. Bakteri Klebsiella sp. memiliki ciri-ciri bentuk batang dan Gram negatif (Sikarwar, 2011). Selanjutnya identifikasi kedua dengan melakukan uji indole, methyl red, voges-proskauer, citrate (IMViC) dengan cara menguji sifat bakteri tersebut jika ditanam pada triple sugar iron agar (TSIA), sulfide indole motility (SIM), simmons citrate agar (SCA), dan methyl red - voges-proskauer (MRVP). Menurut Koneman et al. (1983) bakteri Klebsiella Sp. pada uji IMViC pada uji TSIA yaitu memberikan hasil positif pada acid slant dan acid butt dengan menghasilkan gas, pada SIM yaitu indol dan motilitas negatif, pada SCA positif, pada MRVP yaitu negatif jika ditetesi reagen MR, tetapi memberikan hasil postif untuk reagen VP.

Koloni bakteri Klebsiella sp. disubkultur pada nutrient agar untuk digunakan sebagai inokulum dalam uji kepekaan. Selanjutnya dengan menginkubasi inokulum pada suhu $35-37^{\circ} \mathrm{C}$ selama 2-5 jam, dan setiap 20 menit mecocokan dengan standar kekeruhan sesuai dengan standar Mc Farland 0,5 atau setara dengan $10^{8}$ Colony Forming Unit $(\mathrm{CFU}) / \mathrm{ml}$. Selanjutnya inokulum tersebut ditanam dengan menggunakan cutton swab steril pada media Mueller-Hinton agar, kemudian ditempelkan ketiga disk antibiotika yaitu ampisilin, sulfametoksasol, dan oksitetrasiklin. Setlah diinkubasikan selama 24 Jam diamati diameter killing zone pada masing-masing antibiotika.

Tabel 1. Standar resistensi berdasarkan lebar killing zone

\begin{tabular}{lccc}
\hline \multirow{2}{*}{ Antibiotika } & \multicolumn{3}{c}{ Diameter Killing Zone $(\mathrm{mm})$} \\
\cline { 2 - 4 } Ampisilin & $\leq 11$ & Intermediate & Sensitif \\
Sulfametoksasol & $\leq 12$ & $12-13$ & $\geq 14$ \\
Oksitetrasiklin & $\leq 14$ & $15-16$ & $\geq 17$ \\
\hline
\end{tabular}

Sumber: Koneman et al. (1983)

\section{Analisis data}

Data tentang jumlah bakteri Klebsiella $s p$. yang diisolasi pada sapi bali berdasarkan umur dan lokasi, serta data tentang pola kepekaan bakteri Klebsiella $s p$. akan di analisis secara deskriptif.

\section{HASIL DAN PEMBAHASAN}

\section{Hasil}

\section{Isolasi dan Identifikasi Bakteri Klebsiella} sp.

Pada EMBA sampel yang ditanam memiliki ciri-ciri berkoloni dengan warna merah muda, tepi rata, diameter $2-5 \mathrm{~mm}$, dan bersiat mukoid. Setelah dilakukan pewarnaan Gram tampak bentuk sel bakteri secara mikroskopis dengan pembesaran 1000 kali yaitu ber-Gram negatif dengan ciri tampak berwarna merah dengan bentuk batang pendek. Selanjutnya pada uji katalase dan oksidase, pada uji katalase memberikan hasil positif, sedangkan untuk uji oksidase sampel memberikan hasil yang negatif. Pada uji TSIA menunjukan hasil bahwa sampel yang diuji positif memfermentasi ke tiga gula (sukrosa, glukosa, dan laktosa), dan positif 
memproduksi gas. Pada uji SIM sampel yang diuji menunjukan hasil negatif pada uji indol dan pada uji motilitas juga menunjukan hasil negatif. Pada uji Methyl Red memberikan hasil negatif, sedangkan pada uji Voges-Proskauer meberikan hasil postif. Pada uji sitrat sampel yang diuji juga mmberikan hasil positif.

\section{Distribusi Isolat Bakteri Klebsiella sp.}

Hasil yang didapatkan dari pemeriksaan 120 usapan hidung sapi bali yang berdasarkan tingkat kedewasaan dan lokasi pemeliharaan yang berbeda di provinsi Bali adalah ditemukannya 20 isolat positif bakteri Klebsiella sp. dengan sebaran masing-masing sebagai berikut. Menurut tingkat kedewasaanya dari 20 isolat yang postif bakteri Klebsiella sp. pada sapi pedet isolat yang positif ditemukan sebanyak sembilan isolat (45\%), pada sapi dara sebanyak enam isolat (30\%), dan padi sapi dewasa sebanyak lima isolat (25\%). Sedangkan menurut lokasi pemeliharaanya pada dataran tinggi terdapat tujuh $(35 \%)$ isolat yang positif Klebsiella sp., sedangkan pada dataran rendah terdapat $13(65 \%)$ isolat yang positif Klebsiella sp.

\section{Pembahasan}

Sapi mampu terinfeksi oleh bakteri Klebsiella sp. karena bakteri Klebsiella sp. memiliki sifat patogen potensial dan patogen oportunistik (Sikarwar, 2011). Sapi yang berumur muda cenderung lebih mudah terinfeksi penyakit infeksius seperti infeksi bakteri. Hal ini disebabkan karena pada sapi muda atau pedet antibodi yang dimiliki belum terbentuk, sehingga sistem imunnya belum berkembang seperti halnya pada sapi dewasa, karena pedet hanya memliki imunitas bawaan yang didapat dari kolostrum induknya sehingga pedet lebih mudah terinfeksi agen penyakit seperti bakteri daripada sapi dewasa. Pernyataan tersebut didukung oleh penelitian Riko et al. (2012) yang menyatakan bahwa sistem imun pada hewan terbagi menjadi dua yaitu imunitas bawaan dan imunitas adiptif. Imunitas bawaan didapat dari induk, bersifat non-spesifik dan merupakan pertahanan pertama dalam melawan infeksi. Imunitas bawaan pada hewan muda belum cukup untuk menghadapi agen asing yang ada di lingkungan karena belum cukup berkembang. Sedangkan imunitas adiptif merupakan imunitas yang sangat spesifik sampai terhadap agen patogen tertentu dan bersifat mengingat patogen yang menyerang. Karena imunitas adiptif bersifat mengingat maka imunitas ini akan semakin membaik oleh infeksi yang berulang sehingga hewan yang berumur lebih tua lebih berkembang. Selain itu IgA yang merupakan salah satu sistem pertahanan tubuh sapi pedet pada saluran napas bagian atas belum dapat dibentuk dan hanya diperoleh dari kolostrum induknya (Belli, 2009), sehingga bakteri Klebsiella sp. yang menyebabkan penyakit pada saluran napas atas lebih mudah berkembang pada sapi pedet dibandingkan pada sapi dara dan dewasa.

Secara geografis lokasi peternakan sapi di Bali ada di dua lokasi yaitu dataran tinggi dan dataran rendah (Dewantari et al., 2016). Perbedaan jumlah sampel positif disebabkan oleh suhu pada dataran rendah berkisar antara $24-32{ }^{\circ} \mathrm{C}$, suhu tersebut mendukung pertumbuhan bakteri karena mendekati suhu optimal pertumbuhan bakteri yaitu $37{ }^{\circ} \mathrm{C}$, sehingga bakteri cenderung tumbuh lebih cepat pada dataran rendah. Sedangkan pada dataran tinggi suhu berkisar antara $15-20{ }^{\circ} \mathrm{C}$ dimana pertumbuhan bakteri pada suhu yang rendah cenderung mengalami perlambatan. Pernyataan tersebut sejalan dengan penelitan Kadarsih (2004) dimana lingkungan fisik seperti suhu udara, kelembapan, kecepatan angin, curah hujan, dan ketinggian tempat mempengaruhi peningkatan dan penurunan produksi pada ternak yang di akibatkan penyakit infeksius. Pada suhu rendah seperti pada dataran tinggi pertumbuhan dan aktivitas bakteri cenderung mengalami perlambatan, sedangkan pada suhu yang tinggi seperti pada dataran rendah bakteri cenderung tumbuh lebih cepat. 
Kardarsih (2004) menyatakan bahwa setiap kenaikan 1-10 oC dari suhu optimal ternak maka ternak akan semakin mudah mengalami stress dan semakin mudah terinfeksi penyakit. Kebutuhan zat makanan pada ternak dipengaruhi oleh suhu dan kelembapan, pada suhu yang semakin tinggi dapat menyebabkan menurunnya konsumsi pakan, Penurunan konsumsi semakin berpeluangnya angen infeksi menimbulkan penyakit. Berdasarkan pernyataan-pernyataan tersebut sapi yang dipelihara pada dataran rendah cenderung lebih mudah terinfeksi penyakit daripada sapi yang dipelihara pada dataran tinggi.

\section{Uji Kepekaan}

Hasil uji kepekaan menunjukkan bahwa semua isolat sensitif terhadap ampisilin (100\%). Untuk antibiotika jenis sulfametoksasol sampel yang resisten berjumlah empat isolat (20\%), intermediate berjumlah dua isolat (10\%), dan sensitif sebanyak 14 isolat (70\%). Untuk antibiotika oksitetrasiklin sampel yang resisten berjumlah tujuh isolat (35\%), intermediate berjumlah dua isolat $(10 \%)$, dan sensitif berjumlah 11 isolat (55\%).

Uji kepekaan terhadap antibiotika ampisilin, sulfametoksasol, dan oksitetrasiklin didapatkan hasil bahwa ampisilin lebih efektif jika dibandingkan dengan sulametoksasol dan oksitetrasiklin, dimana seluruh sampel yang positif, peka terhadap antibiotika ampisilin (100\%). Hal ini disebabkan karena ampisilin yang merupakan turunan dari penisilin jarang digunakan untuk bakteri Gram negatif dan lebih sering digunakan untuk mengobati penyakit bakteri dari Gram positif atau bakteri-bakteri yang terdapat pada saluran pencernaan. Pernyataan tersebut sejalan dengan Sharma (2013) yang menyatakan bahwa ampisilin merupakan derivat penisilin yang merupakan kelompok antibiotik $\beta$-laktam yang memiliki spektrum antimikroba yang luas efektif terhadap mikroba Gram positif dan Gram negatif. Ampisilin memiliki spektrum antibiotik yang lebar, tetapi aktivitasnya terhadap mikroba Gram-positif tidak sekuat penisilin G. namun demikian, kelompok ampisilin efektif terhadap beberapa bakteri Gram-negatif. Ampisilin juga efektif digunakan untuk mengobati penyakit seperti infeksi pada saluran pencernaan, saluran urinaria, dan saluran pernafasan (Ashanagar, 2007).

Pada penelitian ini antibiotik jenis sulfametoksasol memberikan hasil resisten sebanyak satu isolat, dan dua isolat intermediate. Hal disebakan karena antibiotika jenis sulfametoksasol cenderung efektif jika diberikan untuk terapa pada saluran pencernaan. Sulfametoksasol biasanya diberikan untuk infeksi saluran urinaria, saluran pencernaan dan infeksi sistemik (Miranda et al., 2008). Karena sifat antibiotika sulfametoksasol yang diberikan untuk infeksi sistemik dan tidak terfokus pada diagnosa dan gejala dari masing-masing bakteri sehingga terjadinya resistensi bakteri semakin mungkin terjadi.

Berdasarkan hasil penelitian antibitoika jenis oksitetrasiklin kurang efektif terhadap bakteri Klebsiella sp. Hal ini disebabkan karena oksitetrasiklin yang bersifat broad spectrum cenderung lebih sering diberikan untuk mengobati penyakit yang disebabkan oleh bakteri, baik itu Gram positif ataupun Gram negatif. Karena terlalu seringnya pemberian antibiotika jenis oksitetrasiklin secara sembarangan tanpa identifikasi yang jelas terhadap bakteri penyebab penyakit tersebut, mengakibatkan kejadian resistensi bakteri terhadap oksitetrasiklin semakin tinggi. Pernyataan tersebut sejalan dengan Boogard et al. (2001) yang menyatakan bahwa idealnya penggunaan antibiotika untuk mengatasi penyakit infeksi harus didasarkan pada identifikasi bakteri yang menyebabkan infeksi, disertai hasil uji kepekaan dari bakteri yang bersangkutan, sehingga akan diperoleh hasil yang maksimal. Pada kenyataannya, hal tersebut sukar untuk dilakukan karena terbatasnya waktu dan kemampuan. Selain itu, dalam menghadapi penyakit infeksi pada ternak, 
maka pengobatan harus dilaksanakan dengan cepat tanpa harus melakukan identifikasi dari agen penyebab penyakit.

\section{SIMPULAN DAN SARAN}

\section{Simpulan}

Klebsiella sp. ditemukan paling banyak pada sapi pedet dibandingkan pada sapi dara dan dewasa, serta sapi yang dipelihara di dataran rendah lebih tinggi kuman Klebsiella sp dibandingkan dengan dataran tinggi. Bakteri Klebsiella sp. sangat sensitif terhadap antibiotika jenis ampisilin dan kurang sensitif terhadap antibiotika jenis oksitetrasiklin.

\section{Saran}

Pengobatan penyakit yang disebabkan oleh bakteri Klebsiella sp. disarankan menggunakan antibiotika ampisilin karena memiliki sensitifitas sebesar $100 \%$. Perlu dilakukan penelitian lebih lanjut tentang antibiotik jenis lain untuk diuji pola kepekaannya dan dilakukan secara periodik atau berkala guna mendapatkan hasil optimal.

\section{UCAPAN TERIMAKASIH}

Melalui kesempatan ini penulis mengucapkan terimakasih yang sebesar besarnya kepada: Rektor Universitas Udayana, Ketua Lembaga Penelitian dan Pengabdian kepada Masyarakat Universitas Udayana, dan Dekan Fakultas Kedokteran Hewan Universitas Udayana atas dana Hibah Unggulan Program Studi (HUPS) tahun 2015 serta fasilitas dan kesempatan yang diberikan.

\section{DAFTAR PUSTAKA}

Ashanagar A. 2007. Analysis of Three Penicillin Antibiotics (Ampicillin, Amoxicillin and Cloxacillin) of Several Iranian Pharmaceutical Companies by HPLC. e-J. Chem. 4(4): 536-545.

Belli HLL. 2009. Peran Kolostrum dalam Transfer Imunitas Pasif pada Anak Sapi Baru Lahir. Wartazoa. 19(2): 76-82.

Boogard AE, London N, Driseen C, Stobberigh EE. 2001. Antibiotic resistence of faeccal eschericjia colli in poultry. Poultry famer and poultry slaughterers. J Antimicrob Chem. (47): 761-771.

Bren A, Hart Y, Dekel E, Koster D, Alon U. 2013. The last generation of bacterial growth in limiting nutrient. Biomed. Central. Syst. Biol. 27(7): 1-9.

Chamdi AN. 2004. Karakteristik Sumberdaya Genetik Ternak Sapi Bali (Bos- bibos banteng) dan Alternatif Pola Konservasinya. J. Biodiversitas. 6(1): 70-75.

Das KC, Qin W. 2012. Isolation and characterization of superior rumen bacteria of cattle (Bos taurus) and potential application in animal feedstuff. J. Anim. Sci. 2(4): 224-228.

Dewantari NRA, Besung INK, Sampurna IP. 2016. Pengaruh Pemberian Mineral Terhadap Jumlah Bakteri Eschericia coli Dan Coliform Pada Sapi Bali Di Dataran Tinggi Dan Dataran Rendah. Bul. Vet. Udayana. 8(1): 71-78.

Gunawan IW, Suwit NK, Sampurna IP. 2016. Pengaruh Pemberian Mineral Terhadap Lingkar Dada, Panjang dan Tinggi Tubuh Sapi Bali Jantan. Bul. Vet. Udayana. 8(2): 128-133.

Jiuhardi. 2016. Kajian Tentang Impor Daging Sapi Di Indonesia. Forum Ekonomi. 17(2): 75-89.

Kadarsih S. 2004. Performans Sapi Bali Berdasarkan Ketinggian Tempat Di Daerah Transmigrasi Bengkulu: I Performa Pertumbuhan. J. Ilmu Pertanian Indon. 6(2): 50-56.

Koneman EW, Allen SD, Dowell VR, and Sommers HM. 1983. Color Atlas and Tetbook of Diagnostic Microbiology $2{ }^{\text {nd }}$ Ed. J.B. Lippincott Company. Philadelphia

Miranda JM, Guarddon M, Vazuquez BI, Fente CA, Barros J, Cepeda A, Franco CM. 2008. Antimicrobial resistance in Enterobacteriaceae strains isolated from organic chicken, conventional chicken and conventional Turkey meat; A comparative survey. J. Food Control. 19: 412-416. 
Buletin Veteriner Udayana

pISSN: 2085-2495; eISSN: 2477-2712

Online pada: http://ojs.unud.ac.id/index.php/buletinvet

Nugraha HY, Sampurna IP, Suata IK. 2016.

Pengaruh Pemberian Pakan Tambahan

Pada Induk Sapi Bali Terhadap Ukuran

Dimensi Panjang Pedet. Bul. Vet. Udayana. 8(2): 159.

Riko YA, Rosidah, Herawati T. 2012. Intensitas dan Prevalensi Ektoparasit Pada Ikan Bandeng (Chanos chanos) Dalam Karamba Jaring Apung (KJA) di Waduk Cirata Kabupaten Cianjur Jawa Barat. J. Perikanan dan Kelautan. 3(4): 231-241.

Sharma SK. 2013. Comparative Study between Penicillin and Ampicillin.
Scholars J. Appl. Med. Sci. 1(4): 291294.

Sikarwar AS. 2011. Identification of Klebsiella Pneumoniae by Capsular Polysaccharide Polyclonal Antibodies. Int. J. Chem. Engine. and Appl. 2(2): 130-134.

Wanapat M, Boonnop K, Promkot C, Cherdthong A. 2011. Effects of alternative protein sources on rumen microbes and productivity of dairy cows. Maejo. Int. J. Sci. and Tech.1323. 